УДК $340[(47)+(51)](091)$

КУРАС Татьяна Леонидовна - кандидат исторических наук, доцент кафедры судебного права Юридического института Иркутского государственного университета (664003, Россия, г. Иркутск, ул. К. Маркса, 1; tanya_kuras@таil.ru)

КУРАС Софья Леонидовна - кандидат исторических наук, доцент кафедры таможенного дела и правоведения Иркутского государственного университета путей сообщения (664074, Россия, г. Иркутск, ул. Чернышевского, 15; kuras@list.ru)

\title{
ДЕЯТЕЛЬНОСТЬ СУДЕБНЫХ ПАЛАТ РОССИЙСКОЙ ИМПЕРИИ И ОРГАНОВ ТЮРЕМНОГО ВЕДОМСТВА НА СТРАНИЦАХ ПАМЯТНЫХ КНИЖЕК
}

Аннотация. В статье исследуются памятные книжки как источник изучения судебных органов и органов тюремного ведомства Российской империи второй половины XIX - начала XX в. Авторы анализировуют количественный и персональный состав должностных лиц указанных органов, их изменения с годами, выявляют существенные отличия размещения информации о служащих данных органов в памятных книжках различных губерний и областей.

Ключевые слова: памятные книжки, суд, Судебная палата, тюрьма, тюремное ведомство

$\Pi$ амятные книжки губерний и областей Российской империи представляют собой официальные справочные издания, включающие в себя широкий спектр сведений о губернии (области) за определенный год. Термин «памятная книжка» включает в себя издания, имевшие разные наименования. Чаще всего использовались заглавия, начинавшиеся словами «памятная книжка», «справочная книга», «календарь», «адрес-календарь». Они издавались в основном местными официальными учреждениями. Эти справочники представляют высокую ценность для исторической науки. Исследование и введение в научный оборот сведений из памятных книжек как важных источников истории Российской империи является значимой научной задачей.

Памятные книжки с годами изменялись и в разных губерниях имели особенности. В полном виде они включали четыре раздела: адрес-календарь (обычно содержал перечень губернских и уездных правительственных и общественных учреждений, их личный состав); административный справочник (как правило, включал сведения об административном делении губернии, почтовых и телеграфных учреждениях, маршрутах сообшения, промышленных и торговых предприятиях, больницах и аптеках, учебных заведениях, музеях, библиотеках и типографиях, периодических изданиях губернии и т.д.); статистический обзор (традиционно здесь содержалась статистика населения, сельского хозяйства, судебных органов, медицины, образования и др.); научно-краеведческий сборник (обычно включал источниковедческие, описательные, научно-исследовательские, археографические и библиографические материалы). Эти части придают изданиям значение комплексных первоисточников для исторических исследований в разных областях. Они помогают проанализировать специфику функционирования территорий империи в динамике.

Помимо прочего, памятные книжки представляют собой значимые источники изучения судебных органов, осуществлявших свою деятельность в Российской империи на основании Судебных уставов 1864 г. Изучаемые источники позволяют, в частности, определить количественный и персональный состав долж- 
ностных лиц судов, проанализировать, как он изменялся с годами. Так, в памятных книжках соответствующих губерний и областей имеется информация о служащих судебных палат, занимавших высокое место в судебной иерархии. Кроме того, эти источники позволяют проследить процесс создания и реформирования тюремного ведомства.

Судебные палаты начали осуществлять свою деятельность в Российской империи в результате проведения Судебной реформы 1864 г. В настоящее время законодатель обоснованно обращается к историческому опыту России, чтобы избежать ошибок в этой области. Это позволяет усовершенствовать законодательство и практику его применения [Сапунков, Сапунков 2014: 194]. В соответствии с законом судебные палаты стали апелляционной инстанцией для окружных судов, а также рассматривали по первой инстанции важнейшие категории дел. Палаты возглавляли судебные округа, на которые была поделена территория страны. В начале XX в. свою деятельность осуществляли 14 палат: Санкт-Петербургская, Московская, Харьковская, Одесская, Казанская, Саратовская, Киевская, Виленская, Варшавская, Тифлисская, Иркутская, Омская, Ташкентская, Новочеркасская [Курас 2011]. По закону судебные палаты возглавлял старший председатель. В их составе работали гражданские и уголовные департаменты, они рассматривали соответствующие дела и возглавлялись председателями. Также при данных судах состоял прокурор, его товарищи, секретарь. В палатах были канцелярии, где работали секретари, их помощники, чиновники и писцы. При палатах состояли судебные приставы, кандидаты на судебные должности и иные лица.

Из памятных книжек можно получить информацию об адресах судебных и тюремных органов. Так, изучение данных изданий позволяет прийти к выводу, что большинство судебных палат и соответствующих окружных судов весь период своей деятельности работали по одному адресу и размещались в одном здании. К примеру, Московская судебная палата и Московский окружной суд размещались в Кремле, в здании судебных установлений ${ }^{1}$. Однако не во всех губерниях была возможность разместить соответствующие палаты и окружные суды по одному адресу ${ }^{2}$. Несомненно, размещение судебной палаты и окружного суда в разных зданиях, а также частые переезды дестабилизировали работу судов, создавали неудобства для населения, однако были обусловлены объективными сложностями.

По данным памятных книжек можно сравнить численный и поименный состав сотрудников тюремного ведомства разных губерний. Так, адрес-календарь Московской губернии содержит сведения о составе служащих в тюремном отделении Московского губернского правления, в нем числилось 15 чел. ${ }^{3}$ В сибирских же тюремных отделениях численный состав каждого тюремного замка составлял не более 3 служащих [Курас Т.Л., Курас С.Л. 2020: 457]. Сведения о должностных лицах судов, ежегодно размещавшиеся в памятных книжках, позволяют исследователям проанализировать различные факторы в динамике. Среди прочего, какой период времени работало данное лицо в конкретном суде, насколько часто имели место перемещения судей и должностных лиц прокурорского надзора в другие судебные органы, как часто повышались в чине служащие палат.

Что касается присвоения чинов, то они в Российской империи давались за

\footnotetext{
${ }^{1}$ Памятная книжка разных учреждений г. Москвы на 1873 г. Типография вед. Моск. город. полиции. Год 2-й. С. 456.

2 Памятные книжки Виленской губернии на 1899, 1906, 1907 г2. Вильна: Губернская типография: на 1899 г. С. 84-86; на 1906 г. С. 53; на 1907 г. С. 55-56.

3 Адрес-календарь Московской губернии на 1895 г. М.: Типография Губернского правления. 1895. С. 7.
} 
службу в порядке постепенности и обозначали степень подготовки служащих, их соответствие должностям. Необходимо было прослужить в каждом классе определенный минимум лет, за заслуги по службе срок мог быть сокращен [Шепелев 1999: 131-132]. Большинство членов судебных палат и должностных лиц прокуратуры палат имели высокие чины действительных статских советников и статских советников, старшие председатели палат нередко имели чин тайного советника. Это свидетельствует об опыте и служебных достоинствах должностных лиц судов. Кроме того, присвоение чинов являлось одной из мер воздействия самодержавия на служащих палат, рассматривавших дела о государственных преступлениях. Чины имели официальное и общественное значение, через них самодержавие стремилось воздействовать на судей, видя в них оплот сушествовавшего строя. В среднем члены палат обычно работали в одном чине 3-4 года.

В характеристике судебных органов в некоторых памятных книжках, помимо общих сведений о служащих судов, содержалась дополнительная информация о кандидатах на судебные должности. Кандидатура на судебные должности значимый институт, направленный на подготовку профессиональных судейских кадров и созданный при проведении Судебной реформы 1864 г. Грамотное решение кадрового вопроса должно было стать залогом успешной реализации судебной реформы [Ильина 2010]. Кандидаты должны были отработать в суде некоторое время, получить опыт и далее могли занимать должности судей. Статус кандидатов регулировался законом, кандидаты делились на старших и младших. Старшие председатели и прокуроры палат определяли их в канцелярии судов, осуществляли общее руководство и контроль за ними, организовывали прием итогового экзамена [Курас 2010: 59-60]. Так, в составе Московской судебной палаты на 1872 г. находились 23 кандидата. При этом в справочной книжке г. Москвы помещена интересная информация о том, в каких учебных заведениях эти лица получали юридическое образование. Большинство из них обучались в Московском университете, некоторые - в лицее князя Безбородко и в училище правоведения ${ }^{1}$. Изучение памятных книжек позволяет выявить служащих судебного ведомства, которые благодаря упорному труду прошли длительный сложный путь от кандидатов на судебные должности до высоких должностей членов, председателей и прокуроров судебных палат [Курас Т.Л., Курас С.Л. 2020: 457-458]. В целом анализ памятных книжек и других источников позволяет сделать вывод, что, несмотря на недостатки правового регулирования, институт кандидатов на судебные должности имел преимущества, позволял молодым людям, получившим юридическое образование, принявшим решение связать свою судьбу с осуществлением правосудия, получить практические навыки, строить карьеру в судах.

Интересно, что в ряде памятных книжек, помимо сведений о фамилии, имени, отчестве и чине должностных лиц судебных органов, содержалась информация об их адресах. Представляется, что такие справки были предназначены, в частности, для ситуаций, когда необходимо было направить письмо служащему суда на личный адрес. В частности, информация о домашних адресах служащих судебных палат содержалась в отдельных памятных книжках Московской, Киевской, Одесской, Казанской, Омской и некоторых других губерний. Изучение указанных изданий за разные годы позволяет сделать вывод о том, насколько стабильной была жизнь должностных лиц судов и их семей, жили ли они длительный период по одному адресу или часто меняли место жительства. В среднем служащие судебных палат жили по одному адресу по 3-4 года.

\footnotetext{
${ }^{1}$ Справочная книжкка разных учреждений г. Москвы 1872 г. Тип. вед. Моск. город. полиции. С. $380-382$.
} 
Интерес представляют и случаи, которые можно выявить при изучении памятных книжек, когда судья и должностное лицо прокуратуры данного суда проживали по одному адресу. Так, к примеру, член Виленской судебной палаты В.В. Луполов и товарищ прокурора данной палаты А.А. Степанов проживали в одном доме 1 . Такое совместное расселение члена судебной палаты и представителя прокуратуры данного суда, на наш взгляд, представляло собой некоторое нарушение принципа независимости судей (данный принцип был провозглашен в качестве одного из основных при проведении Судебной реформы 1864 г. [Шедрина 2014: 65]).

Однако через некоторое время после начала деятельности пореформенных судов власть стала ограничивать их самостоятельность, чтобы они исполняли самодержавную волю. Одним из способов воздействия на судей стал институт назначения на должности. К 80-м гг. XIX в. повышение по службе производилось уже в основном не по служебным заслугам, а по представлению прокуроров. Через них министерство юстиции собирало сведения о судьях, что создавало их фактическую зависимость от прокуроров [Курас 2019: 225]. Исходя из этого, думается, что расселение члена судебной палаты и товарища прокурора суда в одном доме следует расценивать как некоторое нарушение принципа независимости судей, однако такая ситуация была обусловлена объективными причинами, в.т. отсутствием необходимого числа жилых помещений для служащих судов. Особую роль прокуратуры можно выявить и при анализе памятных книжек. Так, в памятной книжке Виленской губернии на 1884 г. в отношении членов судебной палаты изложена только информация о фамилии, имени, отчестве и чине судьи. Что касается должностных лиц прокуратуры, также указано, какими орденами они награждены. Так, прокурор палаты А.В. Волков имел ордена Святого Владимира 3-й степени, Святой Анны и Святого Станислава 2 -й степени ${ }^{2}$. Приведем еще пример: в памятной книжке этой же губернии за 1907 г. у членов палаты адреса не указаны, а у прокурора и его товарищей - указаны ${ }^{3}$. Таким образом, на наш взгляд, даже в изложении информации о составе судебной палаты косвенно подчеркивалось особое, привилегированное положение должностных лиц прокуратуры.

Интересные сведения содержали памятные книжки отдельных губерний. В них, помимо общей информации, описывалась общественная деятельность представителей судебных палат. Такие сведения содержали, в частности, памятные книжки Московской, Казанской, Саратовской, Киевской, Варшавской, Акмолинской, Новочеркасской губерний и областей. Служащие палат не только выполняли служебные обязанности, но и осуществляли общественную деятельность. Они, в частности, участвовали в работе губернских попечительных комитетов о тюрьмах; воспитательно-исправительных ремесленных приютов; российского общества Красного Креста; общества попечительства лицам, отбывшим наказание, и детям бесприютным. Кроме того, они поддерживали деятельность учебных заведений и научных обществ, занимались преподавательской работой. Общественная и педагогическая деятельность представителей судебных палат демонстрировала их активную жизненную позицию, способствовала повышению авторитета судебной власти.

По памятным книжкам как уникальным источникам можно увидеть и взаимосвязь деятельности судебного и тюремного ведомств. Так, в г. Канске Енисейской губернии председательствующим директором отделения

\footnotetext{
1 Памятная книжка Виленской губернии на 1899 г. Вильна: Губернская типография. 1898. С. $380,407$.

2 Памятная книжка Виленской губернии на 1884 г. Вильна: Типография губернского правления. 1883. C. $112-114$.

3 Памятная книжка Виленской губернии на 1907 г. Вильна: Губернская типография. 1907. С. 55-56.
} 
Попечительного общества о тюрьмах был судья окружного суда, что давало возможность взаимодействия двух ведомств 1 . Также, к примеру, в г. Енисейске членом окружного отделения Попечительного общества о тюрьмах был судья окружного суда [Курас Т.Л., Курас С.Л. 2020: 460].

Таким образом, памятные книжки являются важными источниками изучения судов, созданных в Российской империи в соответствии с Судебными уставами 1864 г., а также органов тюремного ведомства. Данные источники позволяют определить количественный и персональный состав служащих судов и органов тюремного ведомства, проанализировать, как он менялся с годами, сравнить состав указанных органов в различных губерниях и областях страны. Также анализируемые издания позволяют выявить, что должностные лица судов, помимо службы, занимались общественной деятельностью, что демонстрировало их активную жизненную позицию.

\section{Список литературы}

Ильина Т.Н. 2010. Кадровое обеспечение судебных учреждений в Российской империи во второй половине XIX - начале XX в.: институт кандидатов на должности по судебному ведомству. - Администратор суда. № 2. С. 31-34.

Курас Т.Л. 2010. Кандидаты на должности по судебному ведомству при судебных палатах Российской империи: общая характеристика, правовое положение. - Вестник Бурятского государственного университета. № 7. С. 58-63.

Курас Т.Л. 2011. Судебные палаты в Российской империи: создание, сравнительная характеристика. - Вестник Иркутского государственного технического университета. № 10. С. 308-310.

Курас Т.Л. 2019. Проблемы взаимодействия судебных палат и прокуратуры во второй половине XIX - начале XX в. в свете реализации принципа независимости судей. - Власть. Т. 27. № 2. С. 224-229.

Курас Т.Л., Курас С.Л. 2020. Памятные книжки Российской империи как историко-правовой документ. - Иркутский историко-экономический ежегодник: 2020. Иркутск: Изд-во БГУ. С. 455-462.

Сапунков А.А., Сапунков Н.А. 2014. Правовые реформы как ответ на глобальные социальные вызовы (уроки судебной реформы второй половины XIX века в России). - Научные труды Сибирского государственного университета физической культуры и спорта. № 19. С. 188-195.

Шепелев Л. Е. 1999. Чиновный мир России: ХVIII - начало ХХ в. СПб. 477 с.

Щедрина Ю.В. 2014. Становление и развитие гарантий обеспечения независимости судей в России во второй половине ХІХ-начале ХХ в.: дис. ... Д.и.н. Курск. $536 \mathrm{c}$.

1 Памятная книжка Енисейской губернии на 1863 г. СПб: Типография Иосифа Огризко. 1863. С. 28. 
KURAS Tat'yana Leonidovna, Cand.Sci. (Hist.), Associate Professor of the Chair of Justice, Law Institute, Irkutsk State University(1 Karla Marksa St, Irkutsk, Russia,664003; tanya_kuras@mail.ru)

KURAS Sofia Leonidovna, Cand.Sci. (Hist.), Associate Professor of the Chair of Customs Affairs and Jurisprudence, Irkutsk State Transport University (15 Chernyshevskogo St, Irkutsk, Russia, 664074; kuras@list.ru)

\section{THE ACTIVITIES OF THE JUDICIAL CHAMBERS OF THE RUSSIAN EMPIRE AND BODIES OF THE PRISON DEPARTMENT ON THE PAGES OF COMMEMORATIVE BOOKS}

Abstract. The author examines commemorative books as a source of study of the judiciary and the prison authorities of the Russian Empire in the second half of the $19^{\text {th }}$ and early $20^{\text {th }}$ century. The authors analyze quantitative and personal composition of the officials of these bodies, their changes over the years and reveal significant differences in the placement of information about employees of these bodies in the commemorative books of various provinces and regions.

Keywords: commemorative books, court, Court Chamber, prison, prison department

\section{УДК 351.74}

ГУРЛЕВ Игорь Валентинович - доктор технических наук, главный научный сотрудник Академии управления МВД России (125171, Россия, г. Москва, улица 3. и А. Космодемьянских, 8; gurleff@ mail.ru)

\section{ОБЕСПЕЧЕНИЕ БЕЗОПАСНОСТИ НА ТРАНСПОРТЕ В РОССИЙСКОЙ ИМПЕРИИ (1797-1917)}

Аннотация. В статье автор показывает эволюцию внутренних транспортных коммуникаций в России с конца XVIII до начала XX в.: от речного, морского и дорожного - к железнодорожному транспорту. Приведены официальные исторические документы, на основе которых власти страны создавали органы обеспечения безопасности на транспорте. Автор исследует деятельность полиции и жандармских полицейских управлений железных дорог, которые обеспечивали не только безопасность, но и бесперебойную работу сети железных дорог. На основе документов Временного правительства автор показывает негативное влияние Февральской революции, которая привела к ликвидации системы безопасности на транспорте.

Ключевые слова: водный, сухопутный, железнодорожный транспорт, жандармское полицейское управление

$\mathrm{B}$ первые пути сообщения в Российской империи выделились в особую отрасль управления при императоре Павле I.

27 февраля 1797 г. (все даты указаны по старому стилю. - Aвm.) Павел I дал указ Сенату (закон № 17.848) «О препоручении водяных коммуникаций во всей Империи в главное ведение и управление Действительного Тайного Советника Сиверса; и о доставлении ему всех нужных по сей части сведений», которым Я.Е. Сиверсу поручалось подготовить предложения об улучшении всех водных коммуникаций в империи 1 .

1 Полное собрание законов Российской империи (ПСЗРИ). Т. XXIV. С 6 ноября 1796 по 1798. СПб. 1830. C. 504-505. 